\title{
Penerapan Akad Murabahah Pada Produk Pembiayaan Pensiun Di BRI Syariah Cabang Kendari
}

\section{Oleh}

\author{
Sulvariany Tamburaka ${ }^{1}$, Muntu Abdullah ${ }^{2}$, Syafila Binti Faisal ${ }^{3}$
}

\begin{abstract}
The purpose of this study was to know the suitability of application akad murabahahin BRI Syariah Branch Kendari withFatwa of National Sharia Concil Number: 04 / DSNMUI / 1 V / 2000 for understand and analyze the suitabilityof murabahah accounting treatment in BRI Syariah Branch Kendari with PSAK 102. The studyused descriptive qualitative method.

The results study showed that the bank represented the client about asset acquisition. At the time of the akad, akad Wakalah and akad Murabahah had been signature at same time. Although the goods (objects of Murabahah) mentioned in the akad do not exist or have not become the legal property of the bank.BRI Syariah Branch Kendari break the PSAK 102 of 2007 because did not to carry out the duty as a seller but as a conventional debt provider. Thetreatment of murabaha accounting based on PSAK 102 at BRI Syariah Branch Kendari in this casethe admission of murabaha assets was appropriate, that wasavowed as the acquisition value. Presentation of akad murabahah financial statement wasagree with PSAK 102, BRI Syariah presents murabahah receivable ofnet value that is value of murabahah receivable after deducting with the allowance loss reserves. The reveal of Akad Murabahah in BRI Syariah that was notagree with PSAK 102 regarding murabahah accounting, because BRI Syariah does not reveal from the purchaser side but only reveal from the seller side.

Based on the results of the study concluded that the application of akad murabaha on pension financing products in BRI Syariah Branch Kendari implemented by including the akad wakalah. In the merging of akad BRI Syariah was not agree with the DSN-MUI fatwa No.4 of 2000 about general stipulations of murabaha in syariah bank at point 4 and point 9. BRI Syariah Branch Kendari break the PSAK 102 of 2007 because did not to carry out the duty as a seller but as a conventional debt provider. Accounting treatment which includes admission of murabaha assets, presentation and disclosure was in accordance with PSAK 102.
\end{abstract}

Keywords: Akad Murabahah, Fatwa of National Sharia Council Number:04/DSN-MUI/1V/2000, PSAK 102.

\section{PENDAHULUAN}

Bank BRI Syariah adalah salah satu Bank Syariah yang berkembang pesat di Indonesia. Untuk memenuhi kebutuhan masyarakat di Indonesia Bank BRI Syariah membuka kantor cabang disetiap wilayah. Pada prinsipnya Bank Syariah menghimpun dana dan menyalurkan dana dalam bentuk pembiayaan. Dalam penghimpunan dana Bank BRI Syariah mempunyai produk tabungan, giro dan deposito, yang menggunakan akad mudharabah dan wadiah. Untuk penyaluran dana menggunakan pembiayaan dalam akad murabahah (jual beli) dan ijarah (sewa menyewa) serta musyarakah. Dalam program pembiayaan salah satu produk yang ditawarkan di Bank BRI Syariah Cabang Kendari adalah Kepemilikan Multifaedah Purna BRI Syariah.

Pembiayaan Kepemilikan Multifaedah Purna adalah pembiayaan kepada para pensiunan untuk memenuhi sebagian atau keseluruhan kebutuhan paket barang atau jasa dengan menggunakan prinsip jual beli (murabahah) atau sewa menyewa (ijarah) dimana pembayarannya 
secara angsuran dengan jumlah angsuran yang telah ditetapkan dimuka dan dibayar setiap bulan. Tujuan diadakannya program pembiayaan pensiunan adalah untuk membantu para pensiunan yang kekurangan atau membutuhkan dana untuk memenuhi kebutuhannya. Manfaat lain dari pembiayaan pensiuanan antara lain memberikan kesempatan dan kemudahan dalam memperoleh pembiayaan, meningkatkan kualitas hidup nasabah, pembayaran angsuran dengan memotong langsung dana pensiunan setiap bulan yang dikelola oleh Bank BRI Syariah Cabang Kendari.

Pembiayaan Pensiun di Bank BRI Syariah Cabang Kendari mulai dijalankan pada Tahun 2016, walaupun produk pembiayaan ini bisa dikatakan baru dalam jasa perbankan syariah akan tetapi produk ini mendapatkan respon yang baik dari masyarakat, sehingga dari tahun ketahun nasabah pembiayaan pensiunan terus mengalami peningkatan. Berdasarkan wawancara awal yang dilakukan oleh peneliti akad pembiayaan untuk produk KMF Purna di Bank BRI Syariah Cabang Kendari yang sering digunakan adalah akad Murabahah. Alasan dipilihnya akad Murabahah dalam pembiayaan adalah karena keuntungan yang diperoleh jelas disebutkan dan disepakati diawal akad. Disamping keuntungan yang jelas diperoleh, adanya agunan yang dapat digunakan untuk menutupi kerugian jika terjadi wanprestaasi oleh nasabah juga semakin membuat Murabahah hampir tidak memiliki resiko.

Jual beli murabahah pada perbankan syariah biasanya dilaksanakan dengan cara menyertakan akad wakalah (murabahah bil wakala) yaitu bank mewakilkan kepada nasabah untuk membeli barang pesanan nasabah dari pihak ketiga, kemudian nasabah memberikannya kepada pihak Bank. Seperti yang tertuang dalam ketetapan fatwa Dewan Syariah Nasional Majelis Ulama Indonesia (DSN-MUI) No. 04/DSN-MUI /IV/2000 pada ketetapan pertama poin ke 9 yaitu jika bank hendak mewakilkan kepada nasabah untuk membeli barang dari pihak ketiga, akad jual beli murabahah harus dilakukan setelah barang secara prinsip menjadi milik bank. Namun kenyataannya beberapa bank syariah dalam melakukan akad murabahah bil wakalah tidak sesuai dengan aturan yang telah ditetapkan oleh DSN-MUI yaitu telah menggugurkan salah satu akad tersebut. Kerap kali pihak bank melakukan akad murabahah sebelum akad wakalah diselesaikan atau barang belum sepenuhnya menjadi milik bank.

Terdapat beberapa penelitian sebelumnya terkait Murabahah bil Wakalah, salah satunya dilakukan oleh Idawati (2018) di Bank Syariah Mandiri Cabang Kendari dengan hasil penelitian, implementasi akad murabahah pada produk pembiayaan pensiunan belum sepenuhnya sesuai dengan fatwa DSN MUI No.04/DSN-MUI/IV/2000. Pada prakteknya Bank juga tidak melakukan pembelian atas nama bank dan akad wakalah tidak dilakukan sebelum dilakukan akad murabahah. Peneliti terdahulu lainnya yang dilakukan oleh Asep Anwar Hidayat (2018) di Bank Syariah Mandiri KC Cianjur yang menyimpulkan Praktik akad murabahah pada produk pembiayaan multi guna dana pensiunan di Bank Syariah Mandiri KC Cianjur tidak optimal dan menyeluruh serta rusaknya akad murabahah sebagai akad utama dalam produk tersebut jika ditinjau dari hukum ekonomi Islam sebagai konsekuensi dari akad murabahah yang pada prinsipnya adalah jual-beli dipraktikan oleh lembaga perbankan syariah tanpa adanya pelaksanaan dan draf akad wakalah terlebih dahulu.

Dalam dunia perbankan penggabungan dua akad dalam satu transaksi merupakan hal yang biasa terjadi, tidak terkecuali di BRI Syariah Cabang kendari. Pihak bank melakukan transaksi pembiayaan pensiun menggunakan dua akad yaitu Murabahah dan Wakalah atau biasa disebut Murabahah bil Wakalah. Alasan pihak bank melakukan penggabungan akad dikarenakan kondisi geografis sehingga bank menyerahkan kuasa kepada nasabah untuk menyelesaikan transaksi kepada pemilik barang yang diminati oleh nasabah tersebut.

Sesuai dengan pemaparan pada latar belakang diatas, maka inti permasalahan yang akan diteliti adalah bagaimana penerapan Akad Murabahah pada produk pembiayaan pensiun di BRI 
Syariah Cabang Kendari?. Tujuan dari penelitian ini adalah untuk mengetahui dan menjelaskan penerapan akad murabahah pada produk pembiayaan pensiun di BRI Syariah Cabang Kendari.

\section{KAJIAN PUSTAKA}

\subsection{Pengertian Akuntansi Syariah}

Menurut Triyuwono (2012:104), akuntansi syariah merupakan salah satu dekonstruksi akuntansi modern kedalam bentuk yang humanis dan syarat nilai dimana tujuan diterapkannya akuntansi syariah adalah untuk mewujudkan terciptanya peradaban bisnis dengan wawasan humanis, emansipatoris, transcendental dan teological.

\section{a. Akuntansi ditinjau dari al-quran}

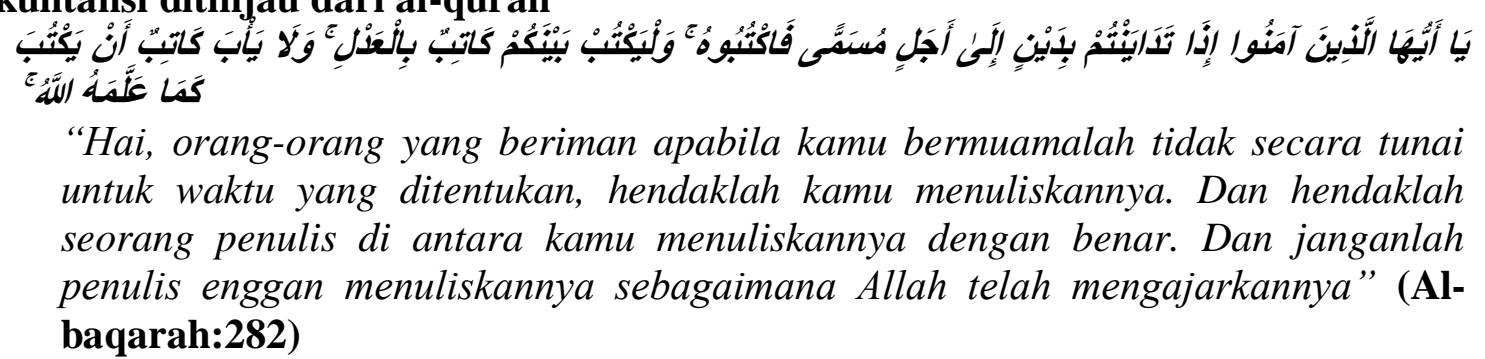

\subsection{Pengertian Akad Murabahah}

Murabahah adalah akad jual beli barang dengan harga jual sebesar biaya perolehan ditambah keuntungan yang disepakati dan penjual harus mengungkapkan biaya perolehan barang tersebut kepada pembeli.

1. Landasan fiqh murabahah

$$
\text { وَأَحَلَّ اللَّهُ الْبَيْعَ وَحَرَّمَ الرِّبَاًَْ }
$$

“Allah telah menghalalkan jual beli dan mengharamkan riba.”(QS Al-Baqarah: 275)

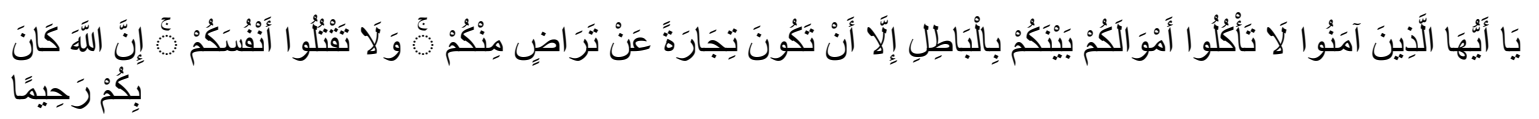

"Hai orang-orang yang beriman, janganlah kamu saling memakan harta sesamamu dengan jalan yang batil, kecuali dengan jalan perniagaan yang berlaku dengan suka sama-suka di antara kamu. Dan janganlah kamu membunuh dirimu; sesungguhnya Allah adalah Maha Penyayang kepadamu." (QS An-Nisa':29)

\subsection{Fatwa Dewan Syariah Nasional MUI No.4 tahun 2000}

Fatwa DSN MUI No. 4 tahun 2000 menetapkan tentang murabahah menyebutkan bahwa ketentuan murabahah dalam Bank Syariah adalah sebagai berikut:

1. Bank dan nasabah harus melakukan akad murabahah yang bebas dari riba.

2. Barang yang diperjual belikan tidak diharamkan oleh syari'ah Islam.

3. Bank membiayai sebagian atau seluruh harga pembelian barang yang telah disepakati kualifikasinya.

4. Bank membeli barang yang diperlukan nasabah atas nama bank sendiri, dan pembelian harus sah dan bebas riba.

5. Bank harus menyampaikan semua hal yang berkaitan dengan pembelian barang, misalnya pembelian dilakukan dengan cara utang.

6. Bank kemudian menjual barang tersebut kepada nasabah (pemesan) dengan harga jual sama dengan harga beli ditambah dengan keutungan dengan memberitahu secara jujur harga pokok kepada nasabah dan biaya-biaya lainnya. 
7. Nasabah membayar dengan harga yang disepakati dan jangka waktu yang telah disepakati antara Bank dan nasabah.

8. Untuk menghindari penyalahgunaan akad pihak Bank dapat mengadakan perjanjian khusus dengan nasabah.

9. Jika bank hendak mewakilkan kepada nasabah untuk membeli barang dari pihak ketiga, akad murabahah harus dilakukan setelah barang secara prisip menjadi milik bank.

\subsection{Pernyataan Standar Akuntansi Keuangan (PSAK) No. 102 tentang Akuntansi} Murabahah

1. Pengakuan dan Pengukuran Murabahah

2. Penyajian Transaksi Murabahah

3. Pengungkapan Transaksi Murabahah

\subsection{Akad Wakalah}

Wakalah menurut bahasa artinya menyerahkan sesuatu. Dalam istilah syara "berarti seseorang yang menyerahkan sesuatu urusannya kepada orang lain, pada apa yang boleh diwakilkan menurut syara" agar orang yang mewakilkan itu dapat melakukan sesuatu yang diserahkan kepadanya selagi yang menyerahkan itu masih hidup.

\subsection{Tinjauan Umum Tentang Murabahah bil wakalah}

\section{Pengertian Akad Murabahah Bil Wakalah}

Akad murabahah bil wakalah merupakan transaksi yang dilakukan dengan menggunakan dua akad yaitu akad murabahah dan akad wakalah. Akad murabahah bil wakalah adalah jual beli dimana Bank mewakilkan pembelian produk kepada nasabah kemudian setelah produk tersebut di dapatkan oleh nasabah kemudian nasabah memberikannya kepada pihak Bank. Setelah barang tersebut di miliki pihak Bank dan harga dari barang tersebut jelas maka pihak Bank menentukan margin yang didapatkan serta jangka waktu pengembalian yang akan disepakati oleh pihak Bank dan nasabah. Akad Wakalah lebih dulu dilakukan sebelum akad Murabahah karena akad Wakalah akan berakhir pada saat nasabah menyerahkan barang yang dibeli pada bank dan mempercepat proses pencairan dan memudahkan nasabah, sehingga setelah barang diterima oleh Bank maka terjadilah akad murabahah.

\section{Rukun Murabahah bil Wakalah}

1. Penjual; yang dimaksud adalah pihak ketiga (supplier)

2. Pembeli; yang dimaksud adalah pihak Bank

3. Barang yang dibeli; adalah barang disepakati antara Bank dan Nasabah

4. Harga (tsaman) yang terdiri dari harga beli margin keuntungan dan harga jual; harga yang telah disepakati oleh pihak Bank dan Nasabah pada awal akad.

5. Pelaku akad, yaitu muwakil (pemberi kuasa) adalah pihak yang memberikan kuasa kepada pihak lain, dan wakil (penerima kuasa) adalah pihak yang diberi kuasa.

6. Objek akad, yaitu taukil (objek yang dikuasakan); dan

7. Shigah, yaitu akad atau perjanjian antara Bank dan Nasabah.

\section{Syarat Murabahah bil Wakalah}

1. Barang yang diperjual belikan harus halal dan bebas dari najis

2. Penjual memberitahu modal yang akan diberikan kepada nasabah

3. Kontrak pertama harus sah sesuai dengan rukun yang telah ditetapkan

4. Kontrak harus bebas dari riba.

5. Penjual harus memberitahu atau menjelaskan bila terjadi cacat atas barang sesudah pembelian. 
6. Penjual harus menyampaikan semua hal yang berkaitan dengan pembelian, misalnya jika pembelian tersebut dilakukan secara utang.

7. Objek barang yang akan dibeli harus jelas dan diwakilkan kepada nasabah yang mengajukan pembiayaan dengan akad murabahah bil wakalah.

\subsection{Pembiayaan Pensiun}

8. Tidak bertentangan dengan syariat islam.

Pembiayaan Pensiun adalah pembiayaan kepada para pensiuanan untuk memenuhi sebagian atau kesuluruhan kebutuhan paket barang atau jasa dengan menggunakan prinsip jual beli (Murabahah) atau sewa menyewa atau ijarah dimana pembayarannya secara angsuran dengan jumlah angsuran yang telah ditetapkan dimuka dan dibayar setiap bulan.

\subsection{Kerangka Pikir}

\section{Gambar 2.1 Kerangka Pikir}

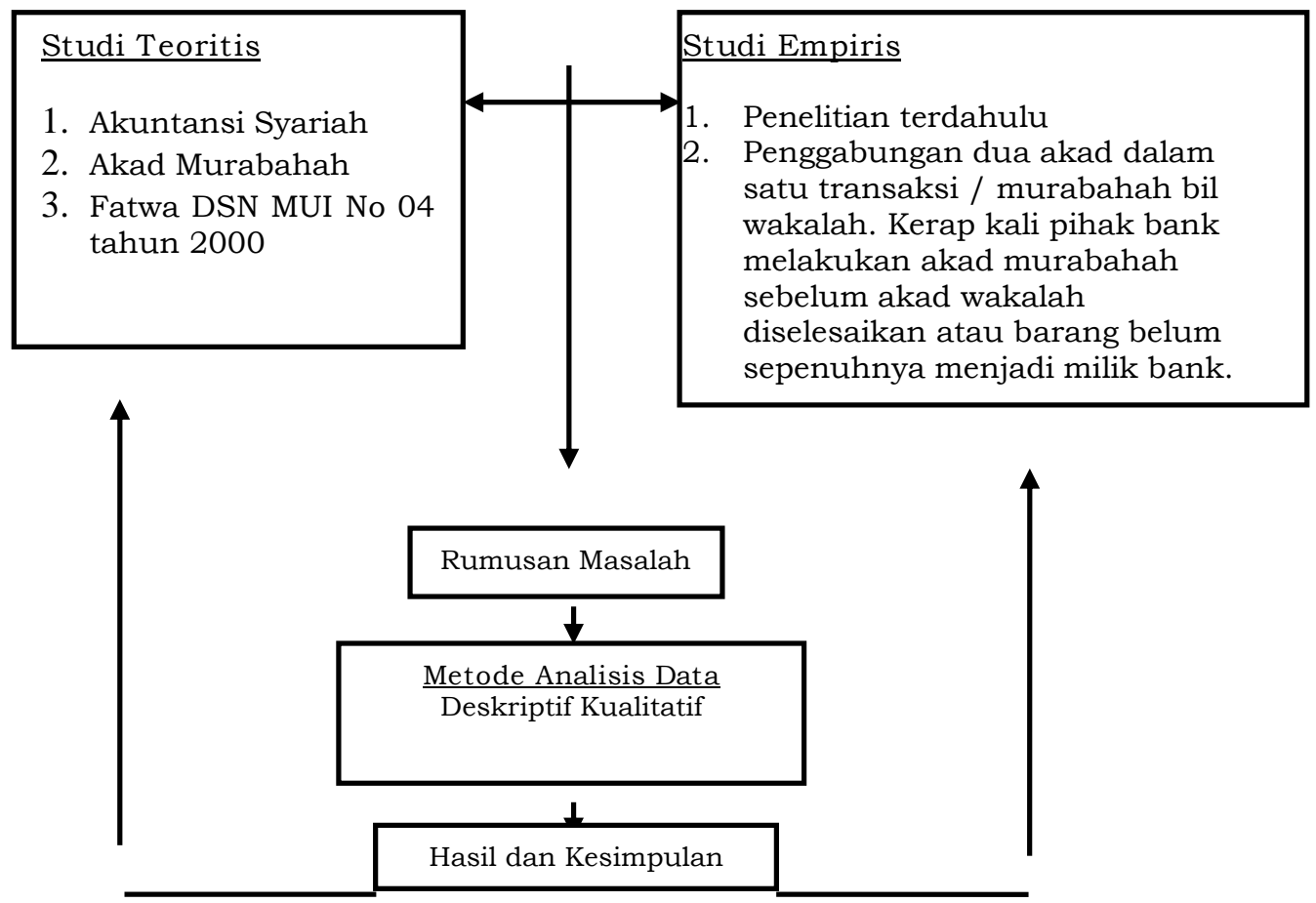

III. METODE PENELITIAN

Objek dalam penelitian ini adalah penerapan akad murabahah pada produk pembiayaan pensiun di bri syariah cabang kendari.

Jenis data yang digunakan dalam penelitian ini adalah data kuanlitatif, adalah yaitu data berupa informasi baik secara lisan maupun tulisan yang berhubungan dengan penelitian ini, misalnya sejarah singkat, struktur organisasi, uraian tugas visi dan misi serta prosedur pembiayaan pensiun di bri syariah cabang kendari.

Sumber data yang digunakan dalam penelitian ini adalah data primer merupakan sumber data penelitian yang diperoleh secara langsung dari bank bri syariah cabang kendari. Dalam penelitian ini, yang termasuk data primer adalah data yang diperoleh dengan wawancara secara langsung dengan pihak terkait, khususnya karyawan bri syariah cabang kendari yang menangani bagian yang berkaitan dengan masalah yang akan diteliti yakni pembiayaan pensiun. Data sekunder adalah data yang diperoleh oleh pihak lain, tidak langsung diperoleh oleh peneliti dari subjek penelitiannya. Data sekunder biasanya berwujud data dokumentasi atau data laporan yang 
telah tersedia. Dalam hal ini data-data berkaitan dengan mekanisme pembiayaan pensiun dengan akad murābaḥah, seperti himpunan fatwa dewan syariah nasional, buku tentang perbankan syariah yang dapat mendukung serta menguatkan data peneliti.

Teknik pengumpulan data dalam penelitian ini peneliti melakukan wawancara terstruktur, dengan menyiapkan instrumen penelitian berupa pertanyaan - pertanyaan tertulis. Selain harus membawa instrumen sebagai pedoman untuk wawancara, pengumpul data juga menggunakan alat bantu seperti tape recorder, gambar, brosur, dan material lain yang dapat membantu pelaksanaan wawancara menjadi lancar. Dokumentasi merupakan teknik pengumpulan data yang dilakukan dengan cara menelaah dokumen yang telah ada atau tersedia yang nantinya digunakan untuk dipelajari pengetahuan dan fakta yang akan diteliti. Teknik ini dilakukan pada saat penelitian dengan mencatat semua catatan, informasi, yang ada di Bank BRI Syariah Cabang Kendari tentang bagaiamana mekanisme pembiayaan pensiun dengan akad murabahah.

Metode analisis data yang digunakan adalah analisis deskriptif kualitatif yaitu mendeskripsikan atau menggambarkan keadaan objek penelitian yang sesungguhnya untuk mengetahui dan menganalisis tentang permasalahan yang dihadapi oleh objek penelitian dengan mengacu pada standar yang telah ditetapkan. Kemudian data yang diperoleh dari hasil wawancara dideskripsikan tentang proses di BRI Syariah Cabang Kendari memperlakukan perihal yang berkaitan dengan pembiayaan pensiun berdasarkan akad murabahah (PSAK 102) serta fatwa-fatwa ulama yang relevan dengan itu (Fatwa DSN MUI No.04/DSN-MUI/IV/2000).

\section{HASIL PENELITIAN DAN PEMBAHASAN}

\section{A. HASIL}

\subsection{Mekanisme Pembiayaan Pensiun di BRI Syariah Cabang Kendari}

Kepemilikan Multi Faedah Purna atau KMF Purna merupakan fasilitas pembiayaan yang diberikan BRI Syariah kepada para pensiunan untuk memenuhi sebagian atau keseluruhan kebutuhan paket barang atau jasa dengan menggunakan prinsip jual beli (murabahah) atau sewa menyewa (ijarah). Pembiayaan pensiun untuk saat ini terbatas pada pensiuanan PNS. Hal ini sebagaimana yang diungkapkan salah satu karyawan BRI Syariah Cabang Kendari melalui hasil wawancara berikut ini: "Pembiayaan pensiun itu adalah salah satu produk dari BRI Syariah dimana yang bertujuan untuk memenuhi kebutuhan finansial para nasabah, yang dalam hal ini nasabah pensiunan, Nasabah pensiunan PNS yah. Jadi masih terbatas dinasabah pensiunan PNS." (Wawancara dengan Bapak Dwinugroho selaku marketing manager di BRI Syariah Cabang Kendari, 23 juli 2019).

Dari hasil wawancara dan brosur menyatakan bahwa Kepemilikan Multi Faedah Purnah atau produk pembiayaan pensiun ini hanya menggunakan akad murabahah dan akad ijarah serta dikhususkan kepada pensiunan PNS saja.Dalam memberikan pembiayaan, BRI Syariah Cabang Kendari memberikan syarat dan ketentuan yang harus dipenuhi nasabah yaitu:

a) Syarat dan Ketentuan

1. Pensiunan PNS

2. Maksimal usia 75 tahun pada saat jatuh tempo pembiayaan

3. Usia minimal 45 tahun khusus bagi janda/duda pensiunan

4. Membuka rekening tabungan di BRI Syariah

5. Blokir tabungan minimal $2 x$ angsuran

6. SK pensiun asli yang diterbitkan oleh instansi yang berwenang

7. SK janda/ duda pensiunan asli yang diterbitkan oleh instansi yang berwenang (jika yang bersangkutan adalah janda/duda dari pensiunan)

8. Pembayaran gaji pensiun melalui payroll BRI/BRISyariah. 
b) Persyaratan Dokumen Nasabah

1. Copy KTP pemohon, KTP pasangan (kalau sudah menikah), dan kartu keluarga

2. SK pensiun asli yang diterbitkan instansi berwenang

3. Copy surat nikah/cerai

4. Copy NPWP pribadi (untuk pembiayaan minimal 50 juta)

5. Copy rekening tabungan gaji pensiun ( 3 bulan terakhir)

6. Copy kartu identitas pensiun (KARIP)

7. Asli slip gaji pensiun terakhir

8. Pas foto pemohon ukuran $4 \times 6$ (suami dan istri)

c) Tahap-tahap Pembiayaan

Nasabah pensiun yang akan mendapatkan pembiayaan harus melalui prosedur yang telah ditentukan oleh pihak bank. Prosedur pemberian pembiayaan pensiunan di BRI Syariah Cabang Kendari adalah sebagai berikut:

1. Tahap permohonan pembiayaan.

Tahap ini nasabah dapat melakukannya dengan dua cara, yang pertama nasabah langsung datang ke Bank BRI Syariah. Cara ini dilakukan nasabah yang biasanya telah mengetahui adanya pembiayaan pensiunan di Bank BRI Syariah Cabang Kendari atau nasabah yang sudah pernah menggunakan Pembiayaan Pensiunan. Selanjutnya nasabah dapat bertemu dengan custumer service atau kepala unit pembiayaan konsumer, atau marketing Pembiayaan Pensiunan (Sales force) untuk menyampaikan permohonan Pembiayaan Pensiun. Cara kedua, melalui Marketing pembiayaan pensiunan (Sales Force). Yang berperan aktif dalam hal ini adalah Marketing Pembiayaan Pensiun dengan cara menawarkan produk pembiayaan pensiun kepada para pensiunan yang membutuhkan pembiayaan. Selanjutnya nasabah yang akan mengajukan pembiayaan mengisi formulir permohonan yang disertakan dengan berkas persyaratan yang diminta oleh pihak Bank sesuai dengan ketentuan persyaratan yang berlaku untuk selanjutnya diproses.

2. Analisis pembiayaan

Tahap selanjutnya setelah menerima dokumen permohonan, maka akan dilakukan BI Checking, pengecekan kelengkapan dokumen seperti identitas diri nasabah, keaslian SK Pensiun, NPWP, keaslian slip gaji pensiun, berapa jangka waktu dan angsuran pembiayaan, Plafon pembiayaan dll.

3. Keputusan pembiayaan

Setelah dilakukan analisis pembiayaan maka tahap selanjutnya pihak A.O (account officer) menginput data permohonan pembiayaan nasabah beserta syarat-syaratnya ke dalam financing approval system (FAS). Setelah mendapat approval maka pihak bank akan membuat Surat Penawaran Pembiayaan (SP3) dan menyusun akad pembiayaan.

4. Penandatanganan akad pembiayaan dan Pengikatan Agunan

Nasabah bertemu dengan perwakilan pihak Bank untuk melakukan akad yang disaksikan oleh notaris. Jenis akad yang digunakan pada pembiayaan pensiun (konsumer) yaitu menggunakan akad Murabahah Bil Wakalah atau akad jual beli, Sedangkan untuk pengikatan agunan yaitu berupa SK Pensiun.

5. Realisasi Pembiayaan

Tahap selanjutnya adalah pencairan pembiayaan oleh Branch Funding Operation (BFO). Dalam proses pencairan pembiayaan akan dimasukkan ke dalam rekening tabungan BRI Syariah milik Nasabah. Jika nasabah belum mempunyai rekening tabungan di BRI Syariah maka nasabah diwajibkan untuk membuka tabungan terlebih 
dahulu. Sebelumnya telah melunasi biaya administrasi yang menjadi kewajiban nasabah.

Hal ini sebagaimana yang diungkapkan salah satu karyawan BRI Syariah Cabang Kendari melalui hasil wawancara berikut ini: "Pada prinsipnya begini pembiayaan pensiun yang pertama tentunya nasabah bermohon ke BRI Syariah. Setelah bermohon kemudian kita cek tuh ke PT Taspen, beliau menerima pensiunan berapa. Kemudian kita BI Checking untuk memastikan pembiayaan pensiun dia itu yang masih berapa dan dimana saja. Dari situ nanti bisa dihitung masih cukup nggak pensiun yang diterima dikurangi kewajiban ditempat lain, setelah kita hitung itu nanti cukup nggak kita realisasikan sesuai permintaan nasabah. Kalau misalkan nggak cukup, kita maksimalkan sesuai kemampuannya nasabah. Kemudian kita kembalikan lagi nasabah mau atau tidak. Kemudian setelah cair tentunya itu nanti rekening nasabah nanti akan diganti. Kalau misalkan nanti ada pembiayaan dibank lain pun kita akan take over (pengalihan utang). serta ketentuannya salah satunya kita yang pertama itu batas usia untuk nasabah 75 tahun saat jatuh tempo, kemudian total angsuran nasabah itu bisa sampai $90 \%$ dari uang pensiun. Misal katakanlah pensiunannya 2 juta, $90 \%$ berarti 1.800 .000 . Jadi kita untuk angsurannya itu bisa 90 persen dari uang pensiun yang diterima"

Hasil wawancara tersebut dapat disimpulkan bahwa prosedur pemberian pembiayaan pensiunan yang mudah dan efektif merupakan salah satu daya tarik bagi nasabah untuk mengajukan pembiayaan pensiunan di Bank BRI Syariah Cabang Kendari. Syarat dan ketentuan pembiayaan pensiun mudah dan tidak menyulitkan nasabah yang ingin mengajukan pembiayaan. Kepuasan nasabah terhadap pembiayaan pensiun di Bank BRI Syariah Cabang Kendari ditujukkan dari sisi jumlah nasabah yang melakukan pembiayaan pensiun dari tahun ke tahun semakin meningkat. Hal senada juga ditegaskan oleh pernyataan berikutnya dari bapak Dwinugroho $\mathrm{R}$ selaku Manager Marketing di BRI Syariah Cabang Kendari melalui hasil wawancara berikut ini: "Pembiayaan pensiun di BRI Syariah sudah sejak tahun 2017, jumlah nasabah dari tahun ketahun selalu meningkat, hingga sekarang jumlah nasabah kami sekitar 150 nasabah" (Wawancara dengan Bapak Dwinugroho selaku marketing manager di BRI Syariah Cabang Kendari, 23 juli 2019).

Semua nasabah pembiayaan Pensiun di Bank BRI Syariah Cabang Kendari selalu tepat waktu dalam membayar kewajiban angsuran pembiayaannya, karena angsuran pembiayaan nasabah telah terpotong otomatis dari rekening pensiun milik nasabah setiap bulannya yang ada di Bank BRI Syariah Cabang Kendari. Hal ini sebagaimana yang diungkapkan salah satu karyawan BRI Syariah Cabang Kendari melalui hasil wawancara berikut ini: "Selama ini nggak ada sih resikonya, karenakan langsung potong gaji, jadi aman. Pembayarannya nanti ketika sudah cair data-data penerima pensiunan diganti menjadi BRI Syariah, jadi setiap bulannya mereka menerima pensiunan itu lewat rekening mereka yang di BRI Syariah. Jadi langsung terpotong jadikan aman" (Wawancara dengan Bapak Dwinugroho selaku marketing manager di BRI Syariah Cabang Kendari, 23 juli 2019).

\subsection{Penerapan akad Murabahah pada produk pembiayaan pensiun di BRI Syariah Cabang Kendari}

BRI Syariah Cabang Kendari dalam menyalurkan Pembiayaan Kepemilikan Multifaedah Purna atau pembiayaan pensiun hanya menggunakan prinsip jual beli (murabahah) dan prinsip sewa menyewa (ijarah). Hal ini sebagaimana yang diungkapkan Manager Marketing BRI Syariah Cabang Kendari melalui hasil wawancara berikut ini: "Murabahah dan ijarah. Perbedaannya yaitu kalau murabahah harus ada wujudnya, misal nasabah mau beli hp akadnya itu murabahah. Tapi ketika nasabah mau mengambil pembiayaan untuk pendidikan akadnya atau untuk umroh 
akadnya itu ijarah. Pokoknya apapun wujudnya yang tidak nyata" (Wawancara dengan Bapak Dwinugroho selaku marketing manager di BRI Syariah Cabang Kendari, 23 juli 2019).

Hasil wawancara tersebut dapat disimpulkan bahwa dalam pembiayaan pensiun ini hanya menggunakan dua akad yaitu akad murabahah dan akad ijarah. Namun pada prakteknya akad murabahah lebih mendominasi pembiayaan pensiun di BRI Syariah Cabang Kendari, Hal ini senada dengan hasil wawancara berikut ini: "Murabahah, karena kebanyakan nasabah ingin beli perabotan rumah, untuk perlengkapan anaknya" (Wawancara dengan Bapak Dwinugroho selaku marketing manager di BRI Syariah Cabang Kendari, 23 juli 2019).

Akad yang digunakan dalam pembiayaan pensiunan di Bank BRI Syariah Cabang Kendari adalah Akad Murabahah dengan menyertakan Wakalah didalamnya karena Bank berperan sebagai penyedia dana. Hal ini sebagaimana yang diungkapkan salah satu karyawan BRI Syariah Cabang Kendari melalui hasil wawancara berikut ini: "Diwakilkan kepada nasabah, karena Bank tidak memiliki barang itu sendiri. Tidak perlu kerja sama karena barangnya sudah jelas, jadi ketika barangnya sudah ada maka kita bisa biayai. Contohnya ketika transaksi nasabah menyatakan saya mau beli barang a terus si Bank kan memverifikasi kepenjual, apakah benar nasabah akan membeli barang a ditempat ini, harganya berapa, dia uang muka berapa. Berarti nanti sisanya pembiayaannya dari Bank" (Wawancara dengan Bapak Dwinugroho selaku marketing manager di BRI Syariah Cabang Kendari, 23 juli 2019).

Hal senada juga ditegaskan oleh pernyataan berikutnya dari Ibu Rasyidathul Fitri selaku staf back office di BRI Syariah Cabang Kendari melalui hasil wawancara berikut ini: "Akad murabahah, tapi bank hanya berperan sebagai penyedia dana" (Wawancara dengan Ibu Rasyidathul Fitri selaku staf back officer, 02 Agustus 2019).

Hasil wawancara tersebut dapat disimpulkan bahwa Bank hanya berperan sebagai penyedia dana atas barang yang telah dibeli secara kredit oleh sinasabah dibuktikan dengan adanya uang muka. Hal ini kembali dipertegas dengan pernyataan berikutnya oleh Bapak Dwinugroho. "Ketika nasabah pembiayaan mengajukan pembiayaan, terus kita analisa kemudian muncul surat persetujuan namanya sp3 (surat persetujuan pembiayaan) nah disitu tertera akadnya apa, harga beli, uang muka, dia mau berapa lama atau berapa tahun jangka waktunya. Kemudian marginnya itu langsung ditetapkan diawal, misal dia membeli barang seharga 120 juta, sudah DP 20 juta. Kita bisa memberikan katakanlah 100 juta yah selama 5 tahun jangka waktunya, nah nanti diterangkan disitu selama lima tahun Bank mengambil keuntungan sebesar misal 50 juta. Jadi harga jual plus margin itu adalah sebesar 150 juta. Jadi 150 juta dibagi 60 bulan sebagai besaran angsuran. Itu harus sudah jelas diawal" (Wawancara dengan Bapak Dwinugroho selaku marketing manager di BRI Syariah Cabang Kendari, 23 juli 2019)

\subsection{Perlakuan akuntansi Murabahah berdasarkan PSAK 102 di BRI Syariah Cabang Kendari}

$\begin{array}{lc} & \begin{array}{c}\text { Studi kasus akad Murabahah } \\ \text { Nurhaerati }\end{array} \\ & \text { MaksimumPembiayaan: Rp } 50.000 .000 \\ \text { Tujuan penggunaan } & : \text { Perabotan rumah } \\ \text { Harga beli barang } & : \text { Rp. } 50.000 .000 \\ \text { Margin } & : \text { Rp. } 15.000 .000 \\ \text { Harga Jual Barang } & : \text { Rp. } 65.000 .000 \\ \text { Uang Muka Nasabah } & : \text { Rp. } 5.000 .000 \\ \text { Harga Jual Barang } & : \text { Rp. } 60.000 .000 \\ \text { Setelah Uang Muka Nasabah } & : \text { Rp.1.250.000 per bulan } \\ \text { Angsuran Pembiayaan } & \end{array}$




\section{Pencatatan Ayat Jurnal Transaksi Murabahah}

BRI Syariah menggunakan PSAK sebagai acuan akuntansi untuk transaksi syariah, salah satunya PSAK No. 102 tentang Akuntansi Murabahah yang digunakan sebagai dasar dari pembiayaan murabahah. Pada praktik Murabahah, BRI Syariah mewakilkan kepada nasabah pembeli untuk membeli barang yang dipesankan atas nama Bank dengan uang muka yang telah diserahkan nasabah kepada supplier adalah sebesar Rp 5.000.000, sehingga BRI Syariah menyerahkan uang tunai kepada nasabah sebesar Rp 45.000.000 yang semula harga perolehan barang sebesar Rp50.000.000. Dengan demikian, pencatatan transaksi piutang murabahah sebagai berikut. Pada saat pihak BRI Syariah memberi kuasa kepada nasabah untuk membeli barang, maka hal ini dibukukan dalam perkiraan piutang murabahah sebesar uang yang diserahkan kepada nasabah, pencatatan akuntansi yang dikeluarkan oleh BRI Syariah, sebagai berikut.

Dr Piutang murabahah Rp. 45.000.000,-

Cr Rekening nasabah-pembeli Rp. 45.000.000,- Berdasarkan hasil analisis perbandingan pada proses pemberian kuasa antara PSAK No. 102 dengan pencatatan yang dilakukan oleh BRI Syariah belum sesuai.

Pada saat nasabah menyerahkan barang atau menyampaikan bukti pembelian barang (barang ditempat nasabah) dan kemudian menyerahkan barang tersebut kepada nasabah, maka BRI Syariah, melakukan pencatatan transaksi sebagai berikut.

Dr Persediaan / Aset Murabahah Rp. 45.000.000,-

Cr Piutang murabahah Rp. 45.000.000,-

Pada saat BRI Syariah menjual barang ke nasabah, berdasarkan hasil analisis pada penerapan akuntansi saat penyerahan barang atau bukti pembelian, pencatatan akuntansi yang dilakukan oleh BRI Syariah, sebagai berikut.

Dr Piutang murabahah Rp. 60.000.000,-

Cr Persediaan Rp. 45.000.000,-

Cr Margin murabahah Rp. 15.000.000,-

Berdasarkan hasil analisis pada penerapan akuntansi saat pelaksanaan akad murabahah telah sesuai dengan PSAK No. 102. Pada saat akad murabahah, piutang murabahah diakui sebesar biaya perolehan aset murabahah ditambah keuntungan yang disepakati.

Untuk pembiayaan ini diharuskan untuk membayar uang muka sebesar yang telah ditentukan oleh supplier. Pada saat nasabah membayar uang muka, maka bank akan mencatat: Pencatatan Akuntansi yang dilakukan oleh BRI Syariah, sebagai berikut.

Dr Kas/rekening-nasabah Rp 5.000.000,-

Cr Hutang uang muka Rp 5.000.000,-

Pengakuan uang muka murabahah juga telah sesuai dengan PSAK No. 102. Dalam hal ini, uang muka murabahah (urbun) diakui sebagai uang muka pembelian sebesar jumlah yang diterima.

Pada saat terjadi akad murabahah dan aktiva murabahah jadi dibeli, pencatatan akuntansi yang dilakukan oleh BRI Syariah, dicatat sebagai berikut.

Dr Hutang uang muka Rp 5.000.000,-

Cr Piutang murabahah Rp 5.000.000,-

Berdasarkan hasil analisis pada penerapan akuntansi saat aktiva murabahah jadi dibeli telah sesuai dengan PSAK No. 102. Dimana uang muka diakui sebagai pembayaran piutang tidak sebagai pembayar angsuran. Pada saat penerimaan angsuran dari nasabah (pokok dan 
margin), BRI Syariah menggunakan pengakuan pendapatan cash basis, yaitu pendapatan baru diakui pada saat kas benarbenar diterima, maka pembayaran angsuran pertama oleh nasabah yang diterima akan dicatat, pencatatan akuntansi yang dikeluarkan oleh BRI Syariah sebagai berikut.

$$
\text { Dr Kas Rp 1.250.000 }
$$

Cr Piutang murabahah Rp 1.250 .000

Hasil analisis perbandingan pada Penerapan akuntansi saat membayar angsuran telah sesuai dengan PSAK 102.

Pada saat nasabah dikenakan denda murabahah, besarnya denda sesuai dengan yang diperjanjikan dalam akad dan dana yang berasal dari denda diperuntukkan sebagai dana sosial (qadrul hasan). Maka, dicatat sebagai berikut. Pencatatan akuntansi yang dikeluarkan oleh BRI Syariah

$$
\begin{gathered}
\text { Dr Kas/ rekening nasabah Rp1.000.000 } \\
\text { Cr Rekening ZIS Rp 1.000.000 }
\end{gathered}
$$

\section{Penyajian laporan keuangan BRI Syariah}

BRI Syariah menyajikan piutang murabahah sebesar nilai bersih yaitu nilai piutang murabahah setelah dikurangi dengan cadangan penyisihan kerugian. Penyajian piutang murabahah dapat ditampilkan melalui Laporan Keuangan Tahun 2018 bagian Laporan Posisi Keuangan per 31 Desember 2018.

Laporan Posisi Keuangan PT BRI Syariah Per 31 Desember 2018 (Parsial Piutang Murabahah, dalam Jutaan Rupiah)

\begin{tabular}{|l|r|}
\hline PIUTANG & 11.575 .070 \\
Piutang murabahah & $(204.194)$ \\
cadangan penyisihan kerugian & 11.370 .876 \\
NETO & \\
\hline
\end{tabular}

Sumber: https://www.brisyariah.co.id

BRI Syariah menyajikan pendapatan murabahah ke dalam kategori pendapatan dari jual beli. Penyajian pendapatan dari jual beli oleh BRI Syariah disajikan secara akumulasi dengan akad jual beli lain pada Laporan Laba Rugi Komprehensif dan secara khusus untuk pendapatan murabahah pada Catatan Atas Laporan Keungan.

\section{Pengungkapan Pembiayaan Murabahah pada BRI Syariah Cabang Kendari}

Pengungkapan transaksi murabahah BRI Syariah mencakup: harga perolehan aset murabahah senilai Rp 50.000.000; dan pengungkapan yang diperlukan sesuai PSAK 101 adalah penyajian Laporan Keuangan Syariah. Berdasarkan hasil analisis dalam pengungkapan, BRI Syariah belum sesuai dengan PSAK 102 tentang Akuntansi murabahah, karena BRI Syariah tidak mengungkapkan dari sisi pembeli tetapi hanya melakukan pengungkapan dari sisi penjual saja.

\section{B. PEMBAHASAN}

Peneliti mendapatkan temuan bahwa:

1. BRI Syariah melanggar PSAK 102 Tahun 2007 karena tidak menjalankan kewajiban sebagai penjual namun sebagai pemberi utang konvensional.

2. BRI Syariah tidak memiliki risiko kepemilikan persediaan karena BRI Syariah memang menghindari risiko gagal pesan dari nasabah, risiko ketidaksesuaian spesifikasi dari nasabah, dan risiko lain seperti cacat dan rusaknya persediaan. 
3. BRI Syariah dikategorikan sebagai lembaga pembiayaan yang memberikan dana kepada nasabah. PSAK 102 (2013) menjelaskan penjual yang tidak memiliki risiko kepemilikan persediaan maka dikategorikan sebagai lembaga pembiayaan dan wajib mengikuti PSAK terkait pembiayaan konvensional. BRI Syariah yang melakukan pembiayaan maka menggunakan PSAK 50, 55, dan 60 untuk memperlakukan akuntansi untuk piutang jangka panjang yang dimilikinya. PSAK 102 (2013) memang tidak mengatur pembiayaan karena entitas yang melakukannya diwajibkan langsung mengacu ke PSAK 50, 55, dan 60.

4. BRI Syariah sebagai penjual sebenarnya tidak menjalankan kewajibannya dengan benar, karena memberikan kuasa kepada nasabah menggunakan akad wakalah saat pembelian persediaan. Nasabah yang memperoleh kuasa pembelian akan menggunakan dana dari BRI Syariah untuk membeli persediaan ke pemasok.

5. Pada perlakuan akuntansi murabahah berdasarkan PSAK 102 di BRI Syariah Cabang Kendari dalam hal pengakuan aset murabahah telah sesuai yaitu diakui sebesar nilai perolehannya.

6. Penyajian laporan keuangan akad murabahah telah sesuai dengan PSAK 102, BRI Syariah menyajikan piutang murabahah sebesar nilai bersih yaitu nilai piutang murabahah setelah dikurangi dengan cadangan penyisihan kerugian.

7. Pengungkapan Akad Murabahah di BRI Syariah belum sesuai dengan PSAK 102 tentang Akuntansi murabahah, karena BRI Syariah tidak mengungkapkan dari sisi pembeli tetapi hanya melakukan pengungkapan dari sisi penjual saja.

\subsection{Penerapan akad Murabahah Bil Wakalah di BRI Syariah Cabang Kendari berdasarkan Fatwa DSN MUI No 4 tahun 2000}

Akad yang digunakan dalam pembiayaan pensiunan di Bank BRI Syariah Cabang Kendari adalah Akad Murabahah dengan menyertakan Wakalah didalamnya. Yang berarti akad Murabahah akan dilakukan setelah Akad wakalah selesai, hal ini berdasarkan Fatwa DSN MUI No.4 Tahun 2000 Tentang Ketentuan Umum Pembiayaan Murabahah poin 9 yang menyatakan : "Jika bank hendak mewakilkan kepada nasabah untuk membeli barang dari pihak ketiga, akad jual beli murabahah harus dilakukan setelah barang secara prinsip menjadi milik bank”.

Bank diperbolehkan memberi kuasa melalui wakalah kepada nasabah untuk bertindak sebagai wakil Bank untuk membeli obyek murabahah sesuai spesifikasi, kondisi, serta harga yang telah disetujui oleh Bank.

Karena dalam hal ini Bank hanya bertindak sebagai penyedia dana, berdasarkan PBI No.10/14/PBI/2007 point ke 1 tentang Murabahah bahwa "Bank bertindak sebagai pihak penyedia dana dalam rangka membelikan barang terkait dengan kegiatan transaksi Murabahah dengan nasabah sebagai pihak pembeli barang".Praktek Murabahah dalam Bank Syariah dikatakan tepat dan sesuai apabila merujuk pada ketentuan Fatwa DSN MUI No.04/DSNMUI/IV/2000 tentang ketentuan Umum Pembiayaan Murabahah dan SEBI No.10/14/DPbs/ Tanggal 17 Maret 2008 tentang pelaksanaan Prinsip Syariah dalam kegiatan penghimpunan dana dan penyaluran dana serta pelayanan jasa Bank Umum Syariah dan Unit Usaha Syariah. Namun pada prakteknya di Bank BRI Syariah Cabang Kendari belum sepenuhnya sesuai dengan fatwa dan Surat Edaran BI yang telah disebutkan sebelumnya.

Analisis kesesuaian implementasi akad Murabahah di Bank BRI Syariah Cabang Kendari dengan Ketentuan Umum Pembiayaan Murabahah berdasarkan fatwa DSN MUI No.04/DSNMUI/IV/2000

Menurut hasil penelitian yang telah dilakukan oleh penulis, dapat dijelaskan sebagai berikut: 
1. Pada point ke 1 yang menyebutkan bahwa "Bank dan nasabah harus melakukan akad murabahah yang bebas riba". Disini terlihat bahwa sesungguhnya BRI Syariah menjalankan praktik riba dengan meminta nasabah mengembalikan dana pinjaman yang diberikan dengan adanya tambahan.

2. Pihak Bank akan melakukan survei untuk memastikan kondisi barang. Maka hal ini sesuai dengan ketentuan fatwa pertama point ke 2 yakni "Barang yang diperjualbelikan tidak diharamkan oleh syari'ah Islam."

3. BRI syariah memiliki standar terhadap barang yang layak untuk dibiayai. Standarisasi tersebut dilihat dari tahun penjualan barang tersebut. Apakah barang tersebut baru (new) atau bekas (second). Jika barang tersebut masih dikategorikan baru maka bank dapat memberikan pembiayaan maksimal $80 \%$ dan sisanya $20 \%$ ditanggung oleh calon nasabah. Apabila barang tersebut bekas maka bank hanya akan memberikan pembiayaan maksimal $70 \%$ (tujuh puluh persen) dan sisanya ditanggung oleh calon nasabah. Hal ini pun sesuai dengan ketentuan fatwa pertama point ke 3 yang menyatakan bahwa "Bank membiayai sebagian atau seluruh harga pembelian barang yang telah disepakati kualifikasinya."

4. Pembelian barang yang diperlukan nasabah tidak dibeli atas nama Bank, melainkan atas nama nasabah sendiri, setelah Bank mentransfer dana dalam jumlah tertentu. Hal ini dilakukan pihak bank agar memudahkan, apalagi barang yang akan dibeli berbeda jenis dan berbeda tempat. Tentunya akan merepotkan bagi Bank jika harus mentransfer satu persatu kerekening supplier. Belum lagi jika ternyata supplier tersebut tidak memiliki rekening bank yang bersangkutan. Walaupun diperbolehkan bagi bank untuk memberikan kuasa kepada nasabah untuk membeli barang melalui akad wakalah, namun pembelian awal yang dilakukan bank melalui perwakilannya (Nasabah) kepada pihak ketiga harus tetap atas nama Bank sampai akad wakalah berakhir dan kemudian dilanjutkan pada akad Murabahah. Jika melihat hal ini maka point ke 4 dalam fatwa DSN-MUI tidak terpenuhi yaitu "Bank membeli barang yang diperlukan nasabah atas nama Bank dan pembelian baru sah dan bebas Riba".

5. Karena pembelian barang diwakilkan oleh nasabah, dalam hal ini berarti nasabah yang harus menyampaikan semua hal yang berkaitan dengan pembelian, dan ini tidak sesuai dengan ketentuan fatwa pertama point ke 5 yang menyatakan "Bank harus menyampaikan semua hal yang berkaitan dengan pembelian, misalnya jika pembelian dilakukan secara utang".

6. Barang yang telah dibeli tersebut kemudian ditentukan harga jualnya dengan perhitungan dari total harga beli ditambah margin yang telah disepakati oleh kedua belah pihak, perhitungan tersebut tertera pada surat perjanjian akad. Sesuai dengan ketentuan fatwa pertama point ke 6 yang menyatakan bahwa "Bank kemudian menjual barang tersebut kepada nasabah (pemesan) dengan harga jual senilai harga beli plus keuntungannya. Dalam kaitan ini Bank harus memberitahu secara jujur harga pokok barang kepada nasabah berikut biaya yang diperlukan."

7. Setelah harga jual barang ditentukan dan besarnya angsuran telah disepakati maka nasabah membayar dengan jangka waktu sesuai kesepakatan, hal ini pun sesuai dengan ketentuan fatwa pertama point ke 7 yakni "Nasabah membayar harga barang yang telah disepakati tersebut pada jangka waktu tertentu yang telah disepakati."

8. Pada pembiayaan pensiun ini, jika terjadi cedera janji maka pihak bank dapat melakukan penyelamatan secara sepihak, sesuai dengan surat perjanjian murabahah yang telah di sepakati kedua belah pihak. Maka sesuai dengan ketentuan fatwa pertama 
pada point ke 8 yang menyatakan, "Untuk mencegah terjadinya penyalahgunaan atau kerusakan akad tersebut, pihak bank dapat mengadakan perjanjian khusus dengan nasabah."

9. Pada saat melakukan akad, penandatanganan akad Wakalah dan akad Murabahah dilakukan dalam satu waktu. Sementara barang (obyek Murabahah) yang dimaksud dalam akad belum ada atau belum menjadi milik sah pihak bank. Hal ini disebabkan karena dana tidak dapat dicairkan jika belum dilakukan penandatanganan akad oleh nasabah. Jika merujuk kembali pada syarat sah Murabahah maka Fatwa DSN MUI point ke 9 tidak terpenuhi "jika Bank hendak mewakilkan kepada nasabah untuk membeli barang dari pihak ketiga, akad murabahah harus dilakukan setelah barang secara prinsip telah menjadi pihak Bank".

Secara prinsip dalam fatwa disebutkan bahwa walaupun Bank tidak memiliki barang dalam bentuk fisik atau tidak berada langsung ditangan pihak Bank namun telah ada nota pembelian sebagai bukti kepemilikan sah. Fatwa tersebut memberikan kemudahan bagi kedua belah pihak karena adanya akad wakalah. Sehingga nasabah dapat membeli dan memilih barang yang diinginkan secara mandiri dan pihak Bank tidak perlu lagi kerepotan memindahkan barang dari supplier kelokasi (Bank) agar dapat diserahterimakan pada saat akad dilakukan. Namun cukup dengan menggunakan nota pembelian dan surat kepemilikan. Dalam hal mewakilkan ini nasabah terlebih dahulu menyerahkan nota pembelian dan surat kepemilikan atas nama Bank kepada pihak Bank sebagai bukti sah kepemilikan atau bukti telah terjadi proses pemindahan kepemilikan dari supplier ke Bank melalui perantara nasabah sebagai wakil Bank dan kemudian barulah akad Murabahah dapat dilakukan.

\section{KESIMPULAN DAN SARAN}

\subsection{Kesimpulan}

Berdasarkan uraian dari bab sebelumnya dapat disimpulkan bahwa penerapan akad murabahah pada produk pembiayaan pensiun di BRI Syariah Cabang Kendari dilaksanakan dengan menyertakan akad wakalah. Dalam hal penggabungan akad BRI Syariah belum sesuai dengan fatwa DSN-MUI No.4 Tahun 2000 tentang ketentuan umum murabahah dalam bank syariah pada poin ke 4 dan poin ke 9. BRI Syariah Cabang Kendari melanggar PSAK 102 tahun 2007 karena tidak menjalankan kewajiban sebagai penjual namun sebagai pemberi utang konvensional. Perlakuan akuntansi yang meliputi pengakuan aset murabahah, penyajian serta pengungkapan telah sesuai dengan PSAK 102.

\subsection{Saran}

1. Bagi Bank, dalam operasionalnya diharapkan tetap menjaga kepatuhan dan konsisten dengan apa yang telah digariskan dalam Fatwa Dewan Syariah Nasional, agar tidak menggugurkan akad murabahah atau jual beli. Alasan yang selama ini selalu dikemukakan pihak bank adalah mereka khawatir barang yang telah dibeli batal diambil oleh nasabah karena tidak sesuai jenis dan kualitasnya. Maka yang perlu dilakukan adalah pihak bank bersama nasabah datang langsung kepada supplier sehingga nasabah dapat memilih barang sesuai kriterianya. Jika menyertakan wakalah maka pihak bank harus bekerja sama dengan berbagai pemasok terpercaya yang menyediakan barang sesuai jenis-jenis komoditas yang biasa dipesan nasabah untuk kebutuhan konsumsi, investasi dan modal kerja.

2. Produk-produk perbankan syariah yang memiliki kejanggalan harusnya menjadi temuan Dewan Syariah Nasional-Majelis Ulama Indonesia dan Bank Indonesia untuk segera dilakukan pengkajian ulang atau menambahkan fatwa dan peraturan secara lebih spesifik 
terkait penyertaan akad wakalah pada pembiayaan murabahah sebagai pedoman dalam operasional bank syariah.

3. Bagi Peneliti selanjutnya, karena penelitian ini hanya terbatas pada pembiayaan pensiun saja, diharapkan untuk dapat memperluas objek penelitian.

\section{DAFTAR PUSTAKA}

Abdullah Saeed. 1996. Islamic Banking and Interest a Study of The Prohibition of Riba and Contempory Intepretation, E. J Brill-Koln.

Al-Arif, M. Nur Rianto. 2012. Dasar-Dasar Pemasaran Bank Syariah. Alfabeta. Bandung.

Ali, Zainuddin, 2008, Hukum Perbankan Syariah, Sinar Grafika. Jakarta.

A Karim, Adiwarman, 2004. Bank Islam Analisis Fiqih dan Keuangan. PT. Raja Grafindo Persada. Jakarta.

Anwar asep. (2018). Aplikasi Akad Murabahah Pada Praktik Pembiayaan Multi Guna Dana Pensiunan Di Bank Syariah Mandiri KC Cianjur. Cianjur: UIN Sunan Gunung Djati Bandung.

Astuti, Ari (2017). Implementasi Akad Murabahah Bil Wakalah Pada Produk Pembiayaan KSPPS Binama Semarang.UIN Walisongo Semarang.

Bank Indonesia dan Otoritas Jasa Keuangan. Statistik Perbankan Indonesian (data sepanjang periode 2014-2018). www.bi.go.id dan www.ojk.go.id

Bikker, Steenback \& Toracchi, (2012). The Impact of scale, Complexity, and Service Quality on the Administrative Costs of Pension Funds: A Cross-Country Comparison. The Journal of Risk and Insurance, https://doi.org/10.111/j.1539-6975.2011.01439.x

Departemen Agama RI. 2006. Al-Aliyy Al-Qur'an dan Terjemahannya. CV Diponegoro. Bandung.

Fatwa Dewan Syariah Nasional Nomor: 04/DSN-MUI/IV/2000 Tentang Pembiayaan Murabahah. Jakarta.

http://www.landasanteori.com/2015/10/pengertian-dana-pensiun-defenisi-jenis.html

http://www.materibelajar.id/2015/12/definisi-implementasi-dan-teori.html

Hasanudin, Habib Nazir, 2004. Akuntansi Islam, Bumi Aksara. Jakarta.

Hendry Arrison, (1999). Perbankan Syariah. Muamalah Institute. Jakarta.

Idawati. (2018). Implementasi Akad Murabahah pada Produk Pembiayaan Pensiun di PT Bank Syariah Mandiri Kantor Cabang Kendari. IAIN Kendari. Kendari.

Ikatan Akuntansi Indonesia. 2010. Pernyataan Standar Akuntansi Keuangan Nomor 102 tentang Akuntansi Murabahah. Jakarta.

Jonathan, Sarwono. (2006). Metode Penelitian Kualitatif dan Kuantitatif. Graha Ilmu. Yogyakarta.

Khadafi,Muammar,dkk.2016. Akuntansi Syariah: Meletakkan nilai - nilai syariah islam dalam ilmu akuntansi. Edisi Pertama, Madenatera. Medan.

Muhammad. 2005. Manajemen Bank Syariah. Yogyakarta.

Nazir, Habib, dan Muhammad Hasanuddin. 2004. Ensiklopedi Ekonomi dan Perbankan Syariah Cet. Ke-1, Kaki Langit. Bandung.

Nurhayati sri, Wasilah. 2014. Akuntansi Syariah di Indonesia. Edisi Ketiga. Salemba Empat. Jakarta.

Nurtika, (2017). Pelaksanaan Akad Wakalah Dalam Pembiayaan Murabahah Di PT BPRS Bumi Artha Sampang Kantor Cabang Cipari, Cilacap, Jawatengah. IAIN Jawa Tengah.

Nussy, 2014. Analisis Penerapan PSAK No.18 Mengenai Akuntansi Dana Pensiun pada PT. Taspen Cabang Manado. Jurnal EMBA, Manado. 
Prabowo, Bagya Agung. Konsep Akad Murabahah Pada Perbankan Syariah (Analisa Kritis Terhadap Aplikasi Konsep Akad Murabahah Di Indonesia Dan Malaysia) Dalam Equality, Jurnal Hukum, Fakultas Hukum Universitas Sumatera Utara.

Peraturan Bank Indonesia tentang pelaksanaan prinsip syariah dalam kegiatan penghimpunan dana dan penyaluran dan serta pelayanan jasa bagi bank syariah PBI No. 9/19/PBI/2007. Pasal 3. Republik Indonesia, 1979.

Peraturan Pemerintah Nomor 32 Tahun 1979 Tentang Pemberhentian Pegawai Negeri Sipil.

Sjahdeini, Sutan Remy. 2014. Perbankan Syariah Produk-Produk dan Aspek-aspek Hukumnya, Jakarta.

Triyuwono, Iwan. 2012. Akuntansi Syariah perspektif, metodologi, dan Teori. PT Raja Grafindo Persada. Jakarta.

Undang-Undang Nomor 21 Tahun 2008 tentang Perbankan Syariah, Jakarta.

Undang-Undang Nomor 10 Tahun 1998 tentang Perbankan, Jakarta.

Undang-Undang Negara Republik Indonesia Nomor 43 Tahun 1999 Tentang

Perubahan Atas Undang-Undang Nomor 8 Tahun 1974 Tentang Pokok-Pokok Kepegawaian, LNRI Tahun 1999 Nomor 169, TLNRI Nomor 3890

Undang-Undang Republik Indonesia Nomor 11 Tahun 1969 Tentang Dana Pensiun, Jakarta.

Zulkifli, Sunarto. 2003. Panduan Praktis Transaksi Perbankan Syariah. PT Zikrul Hakim. Jakarta. 